\title{
Strategic alliances, organisational learning and new product development: the cases of Rover and Seat
}

\section{María José Álvarez Gil ${ }^{1}$ and Pedro González de la Fé2}

\author{
${ }^{1}$ Departamento de Economia de la Empresa, Universidad Carlos III de Madrid, c/Madrid 126, 28903 Getafe, \\ Spain \\ ${ }^{2}$ Universidad de las Palmas de Gran Canaria, Edificio Departamental de CC.EE.EE., Modulo D, Campus de \\ Tafira, 35017 Las Palmas de Gran Canaria, Spain
}

\begin{abstract}
The importance of the automotive industry in the global economy is widely recognised. The sector has undergone enormous changes in order to prepare for the fierce competition of the 21st century. Among these transformations, the most relevant are those technologies developed for the rapid evolution of activities linked to new designs, new products, and new manufacturing processes and systems. Innovative Japanese carmakers have stimulated international performance comparisons in these activities.

International technology alliances may be one way of gaining access to new competitive technologies. Risks and costs associated with new product development can be shared among the partners and more effective use can be made of manufacturing facilities and production capabilities. Sometimes, an alliance agreement may lead to the deployment of new capabilities. However, in spite of this potential, the literature presents the success rate of alliances at less than $\mathbf{5 0 \%}$.

Our study considers two examples of companies that developed international joint ventures (IJVs): Rover with Honda, and Seat with Volkswagen. Since these two European peripheral companies, Rover and Seat, no longer remain as independent firms, we are interested in identifying the reasons leading to the success or failure of these IJVs as regards the New Product Development (NPD) process. In particular, in both cases the paper looks at the problems of the weaker partner becoming increasingly dependent on the other partner and the need for a well-defined strategy to benefit from IJVs.
\end{abstract}

\section{Introduction}

A fter the merger and acquisition boom of the 1980 s, the decade of the 1990s has been characterised by the growth of strategic alliances and international joint ventures (IJVs). In this sense, Inkpen $(1998$, p. 224) estimates that the number of strategic alliances formed has grown by more than $25 \%$ since 1990 .

In the context of this article, the concept of strategic alliance is defined as a long-term co-operative arrangement between two or more independent firms that engage in business activities for mutual economic gain' (Tsang,
1998, p. 209). Such an arrangement can prepare the companies for competitive positioning (Sørensen and Reve, 1998, p. 151), allowing them to gain sustained competitive advantage vis-à-vis their competitors outside the alliance (Jarillo, 1988). By joint venture (JV) we imply a means of performing activities in combination with one or more firms instead of autonomously (Inkpen and Crossan, 1995, p. 595). We will limit our research to the concept of strategic technology partnering suggested by Hagedoorn and Narula (1996), which involves contractual alliances covering a relatively large group of partnerships, such as joint development agreements, joint research programmes, 
cross licensing, second-sourcing agreements, mutual second sourcing, and R\&D contracts. Partners can cooperate in certain areas, but they still compete with each other in other areas (Hamel, 1991; Pucik, 1988); such a context has been described by Schill et al. (1994, p. 262) as a horizontal alliance scenery.

Although strategic alliances devoted to developing new assets (technology) represent an important target for research (Sørensen and Reve, 1998, p. 151), work on strategic alliances and international joint ventures has recently begun to address issues of organisational learning, learning opportunities and renewal. (See Anderson, 1990; Dogson, 1993; Hamel, 1991; Inkpen, 1995; 1998; Inkpen and Beamish, 1997; Inkpen and Crossan, 1995; and Simonin and Helleloid, 1993, for further detail.) Different authors, such as Teece and Pisano, 1994; Hamel, 1991; Huber, 1991; Inkpen and Crossan, 1995; Kogut, 1988; Ritcher and Vettel, 1995; and Westney, 1988; have suggested that alliances may be signed with the primary goal of learning from partners, because both alliances and IJVs provide a platform for organisational learning, giving access to the skills and capabilities of the partners. Furthermore, Grant and Baden-Fuller (1995) affirm that through 'learning alliances' firms can speed capability development and minimise their exposure to technological uncertainties by acquiring and exploiting knowledge developed by others.

However, recent work on alliances and the role of firms specificity knowledge in firm strategy (Mowery et al., 1996, p. 78) suggest that firms use interfirm collaboration to gain access to other firms' capabilities, supporting more focused, intensive exploitation of existing capabilities within each firm. The implicit requirement here is that one of the partners is technologically stronger than the other, so that the stronger, or 'teacher', would not learn too much from the weaker, or 'student' firm. This means that one of the partners, the 'student', is looking to the alliance for some kind of organisational learning, while the other is looking for other kind of outcomes. Some student firms may decide to become and remain dependent on the teacher firm, in the conviction that they would gain progressive access to the teacher's knowledge, in spite of the fact that they may in fact have very limited chances to continue learning through the alliance.

So far, international technology alliances may be one option to gain access to new competitive technologies. Risks and costs associated with new product development can be shared among the partners and more effective use can be made of manufacturing facilities and production capabilities. Sometimes, an alliance agreement may lead to the deployment of new capabilities. However, in spite of this potential, the literature presents the success rate of alliances at less than $50 \%$. Our study considers two examples of companies that developed international joint ventures (IJVs): Rover with Honda, and Seat with Volkswagen.
Since these two European peripheral companies, Rover and Seat, no longer remain as independent firms, we are interested in identifying the reasons leading to the success or failure of these IJVs as regards the New Product Development (NPD) process. In particular, in both cases the paper looks at the problems of the weaker partner becoming increasingly dependent on the other partner, and the need for a well-defined strategy to benefit from IJVs.

The article is organised as follows. We introduce in Section 2 the state of the art and suggest a research question. In Section 3 we consider the Rover and Seat cases, including a parsimonious description of the contents of both alliances. Section 4 is devoted to analyse and compare the results of the alliances. Managerial implications and suggestions for future research are provided in Section 5.

\section{State of the art and research question}

Savary (1995, p. 149) has described the challenges faced by European and American car manufacturers in the 1980s. First, since the demand grew more slowly, competition became more acute. Secondly, products and process innovations led to changes in the competitive priorities, increasing the concern for higher quality and lower costs and prices. Thirdly, the surge of the Japanese firms with their 'lean approaches' to production and operations management. As a consequence, the European automobile production system saw a major change in the eighties (Hudson and Schamp, 1995, p. 224).

The automobile producers operating in Europe, willing to increase size, reduce costs and improve competitiveness, followed two strategic responses in the late eighties. First, they tried to increase their R\&D and manufacturing activities, in order to acquire quality levels similar to those of their Japanese competitors, as well as to reduce the costs. Second, they reinforce the development of international cooperation agreements as a means of increasing efficiency. It was done either through direct investments and exports, or by signing strategic alliances. These agreements could involve European firms, like Renault and Volvo in 1990, aiming at reaching economies of scale, but they were also oriented at enlarging the product range, with new specialised vehicles and new key components, such as engines or transmissions and/or new car models. The 1982 agreement between Seat and Volkswagen can be considered a prototype of this approach. In spite of the fact that it was unusual to sign agreements with the Japanese as a route to learning about their manufacturing approaches - like lean production - Rover signed an agreement of this kind with Honda.

Glaister and Buckley (1996, p. 304) have proposed several reasons to explain why strategic alliances have 
become so trendy in the automotive industry (See Table 1). Firstly, the production process in the automobile sector is characterised by economies of scale and learning by doing; thus, firms may attempt to reduce costs expanding out to achieve these benefits. Strategic alliances allow firms in the same industry to rationalise production while avoiding the uncertainties and difficulties of full-scale merger (Mariti and Smiley, 1983; Contractor and Lorange, 1988). Secondly, strategic alliances may be used as a defensive ploy to reduce competition (Harrigan, 1985). Alternatively, linking with a rival in order to put some pressure on the profits and market share of a common competitor may use an alliance as an offensive strategy. Thirdly, the alliance formation may help firms to move to new foreign markets and to the development of either a multi-domestic or global strategy (Gannon, 1993). In fourth place, the alliances may be used to bring together complementary skills and talents that cover different aspects of the know-how needed in high technology industries, as well as the necessary manufacturing, scale and distribution outlets.

These proposals are complementary to the suggestions of Hagedoorn and Narula (1996) who have demonstrated that international strategic technology partnering in high-tech industries appears to be disproportionately organised through contractual arrangements, whereas other sectors with lower levels of technological sophistication have a higher share of joint venturing. The automotive industry occupies an intermediate situation between high and medium technological levels; thus, the probability of finding joint ventures and contractual agreements is very high. Due to that peculiarity, Kobayashi (1988) suggested the relationships between the need for continual updating of the car makers capabilities and the strategic alliances as facilitators of this up-to-date. More recently, Hayes et al. (1996) have proposed that this trend is also strongly related to the aim of building skills in new market sectors, such as the small cars in the USA, or the fourwheel drive, leisure vehicles, in Europe.
The outstanding problem is that strategic learning horizontal alliances may involve a high risk of instability, partly due to the array of diverse situations that may happen. For instance, one of the partners may have a limited incentive to share its knowledge if such sharing could potentially lead to the creation of a competitor, as suggested by Inkpen (1998, p. 225). These situations are constrained to what has been termed by Schill et al. (1994, p. 262) as "precompetitive' activities. There is also the risk that one partner may acquire knowledge that it lacked at the time of the alliance formation, and as soon as this knowledge is acquired, such a partner may decide to cease the joint venture. It might happen as well that a dependent relationship develops, as the weaker partner (i.e. the one with less developed knowledge) does not learn as expected and this fact prevents it from reacting on time to the increasing pace of new products and processes innovations that its partner and competitors are developing.

This late situation can be the final result of what Nakamura et al. (1996) has described as 'divergent development', i.e., partners decline technological overlap, so that the alliance is meant as a vehicle for accessing rather than acquiring capabilities. In the short term, the alliance appears to be the cheapest way to source investments in R\&D processes, NPD activities, etc. and such sequential but scarce access to knowledge could be considered by the student firms as an enabler of their future independence from the teacher partner. However, by proceeding this way, the student firms may lose the required level of selfawareness to quickly react to the market forces that inevitably rode the combined strategic value of their sets of capabilities' (Lane and Lubatkin, 1998, p. 474). Consequently, it is very likely that these firms will compromise their chances of developing effective new capabilities on its own and they will probably be unable to identify their future best-qualify teachers.

Thus, in this article we try to demonstrate that weaker partners willing to achieve a sustainable

Table 1. Alliances in the automobile industry prior to 1986.

\begin{tabular}{lll}
\hline Firm & Joint venture & Procurement \\
\hline${ }^{*}$ Volkswagen (Germany) (includes Audi) & & Seat, Nissan \\
${ }^{*}$ PSA (France) (Includes Peugeot and Citröen) & Renault, Volvo & \\
${ }^{*}$ Renault (France) & PSA & Honda \\
${ }^{*}$ Rover (U.K.) & Toyota, Daewoo & Nissan \\
General Motors (USA) (includes Opel, Vauxhall) & & \\
Ford (USA) (includes Ford Europa) & & \\
Chrysler (USA) & General Motors & General Motors, Volkswagen \\
Toyota (Japan) & Alfa Romeo & Daimler Benz \\
Nissan (Japan) & & \\
\hline
\end{tabular}

${ }^{*}$ European Company

Source: Burgner, 1986 
competitive advantage should try to acquire a specific knowledge, and develop a thorough understanding of its own knowledge, i.e. the processes by which it converts knowledge to capabilities, and the ability of these capabilities to meet the demands of its environment, instead of limiting themselves to gain access to it from their strong partners. We try to demonstrate as well that clearly stated corporate strategies can be of enormous help when trying to avoid the trap of become dependent from the stronger partners.

\section{The research set and descriptions}

In this section we explore the strategic alliances signed by Rover and Seat with Honda and Volkswagen, respectively, in the early 80 s. They can be considered two examples of horizontal alliances, where two technologically weak companies looked for gaining access to the skills and knowledge of stronger partners.

Different researches have claimed that the complexity of strategic alliances and IJVs has been a major obstacle for their studies. Looking for a reasonable solution to such a problem, we have used multiple sources of data as a means of gaining a more complete picture of the phenomenon we are looking at. The first source of data is one in-depth case study of Seat, developed by Álvarez and González (1997) and conducted between 1993 and 1997. This case was confronted with international literature on the Rover case. We are particularly in debt with Pilkington (1996, 1998), whose research work gave us access to a very well documented knowledge on the British company. He prepared the Rover case using data gathered from public sources, action research and interviews conducted between 1987 and 1994 (Pilkington, 1996b), when the company was finally acquired by BMW and the Honda relationship ended.

A second source of data generated additional support for the importance of the research questions. This data source is longitudinal and it is related to a former project initiated by one of the authors (González, 1998). He has studied the complete evolution of Seat from its early days till 1996, analysed the company reports and accounts, and interviewed significant representatives of the former Spanish firm. He has also checked the Seat financial figures against those shown by the other automobile producers operating in Spain along the 1982-1992 period. The idea of studying a longitudinal data source was inspired by Doz (1996) and Geringer and Hebert (1991) suggestions. They complain that, in spite of the relevance of the effects of technological dependence, the available literature lacks of a clear view of the way in which capabilities and strategies are conditioned by the historical development of the parties concerned.

\subsection{Rover and Seat}

3.1.1. Rover. As it has been described by Barrie (1995), Bertodo (1990), Hudson and Schamp (1995), Pilkington (1996a,b, 1998), and Schill et al. (1994), among others, we have to look at the historical development of the firm to understand the reasons which led Rover to enter the relationship with Honda.

In the first years of the decade of the seventies, most of Rover's products lines were outdated and unprofitable and its dimension was not adequate to benefit from scale economies, making it quite difficult for the carmaker to react to European and Japanese competitors. Austin Rover had the skills and resources to develop replacement models, but its programmes to replace its ageing models were behind schedule. After the merger of the majority of the British motor industry, i.e. Austin, Morris and Leyland, in 1973, the 'new' company was renamed British Leyland Motor Company (BLMC), and it was expected that this merger would allow to cut costs and retain market share (Pilkington, 1998, p. 2). Nevertheless, BLMC was unable to match the R\&D levels of its main competitors: Ford UK and Vauxhall (GM). Suffering from strong financial problems, the firm invited the Government to intervene and the group was nationalised in December 1974.

The Ryder Plan Report, a Parliamentary study dated 1975, pointed out several important problems in BLMC, such as out-dated machinery and facilities, weak organisational structure and lack of a common rational plan for all merged plants. In 1977 a new name, BL, was given to the firm and a new Managing Director, Michael Edwardes was appointed; his main task was to rationalise the models and markets of the company. The rationalisation exercise led to close down Speke and Seneffe in Belgium, as well as to dismantle some production lines at Cowley, and the Land Rover and Range Rover plant at Solihull. It implied to halve the production volume between 1977 and 1980. Furthermore, the plant near Oxford was reorganised to manufacture upper and medium cars. One challenging task was to radically change the bad reputation of the vehicles (poor quality and reliability) and to renew the product range. It seemed a difficult task to be accomplished, since the design resources were very much chaotically mixed and had been cut in the belief that high volume manufacturing would become the solution for BL. Under such scenery, the new managing director considered that a Japanese partner would be much more convenient than a European, and BL and Honda did at least have something to offer each other (Pilkington, 1998, p. 3).

The 1979 deal with Honda was intended to provide a car model to produce for two or three years while the Montego/Maestro design was being completed. As Pilkington (1998, p. 3) emphasises, 'Honda had design strengths in just the areas that had been allowed to let slip under the BL reorganisations: engines and gear- 
boxes. BL, for its part, had European design studios, which would improve the styling of the Japanese products and make them more attractive to customers both at home and abroad. Honda's strength of organisation and efficient methods of production, together with the products themselves, were also seen by Edwardes as desirable role models to follow'.

3.1.2. Seat Seat started its activity in 1950. Its shareholders were several Spanish banks and Fiat, the Italian carmaker; this firm occupied several positions at the advisory board, provided the Spanish company with the required process technology and technical assistance, and gave the licences for the manufacturing of the Spanish versions of the Fiat models. It was not until 1967 that Seat began to be concerned about its lack of strategic planning and its corresponding weaknesses in the technical and organisational infrastructure. To make things worse for Seat, the Spanish Government changed the regulatory framework in 1972, facilitating the opening by Ford of a factory near Valencia, wherein the Ford Fiesta model was manufactured.

Between 1974 and 1979, Seat's share of the Spanish market declined from a $51.2 \%$ in 1974 to a $29.94 \%$ in 1979. Along this five-year period, the company concentrated most of its efforts in the manufacturing and distribution of the Seat 127 model (Álvarez and González, 1997). However, there was so much idle manufacturing capability that Seat managers considered that marketing activities would have to be reinforced, so that manufacturing capacity could be fully used. But the export figures suffered a continuous decline: Seat was not fully integrated in a multinational firm, and it lacked all capabilities related to R\&D and New Product and Process Development. Then, Seat asked Fiat for financial help and technical support. The Italian company was facing important internal troubles (Conti and Enrietti, 1995) and it refused to maintain its share in Seat. So far, by 1981 the publicly owned Spanish holding, INI, ${ }^{1}$ took care of Seat and Fiat ended its relationship. Table 2 summarises these facts. Seat was not competitive at all, since it needed (i) to reduce its costs; (ii) to increase quality levels, (iii) to build the capabilities related to product variety and readiness for model changes, (iv) to increase customer satisfaction levels and to renew the product-mix.

These problems were well known by Seat executives and were reflected in the (1982-1986) Corporate Strategic Plan. Its long- term objectives were formulated as:

- to continuously keep an up-dated products range;

- to launch new models, easy to export to both South America and Europe;

- to develop two new models, completely designed and engineered by Seat, known as the models Ibiza and Málaga; and
- to launch new models, renewed versions of already existing Volkswagen vehicles, like the Polo model and its versions, and the Passat and Variant models.

\subsection{The alliances and the development of new products}

3.2.1. Rover and Honda. An analysis of the portfolio of Rover products provides evidence of its reliance on Honda for design and development programmes (see Table 3). The 800, 600, 400 and 200 series belong to the period of the joint development with Honda. Pilkington (1998, p. 9) affirms that Rover could produce the ageing Metro and Mini models independently; the problem was that these models were relatively unprofitable and they did not represent a means of securing Rover's future; only the Rover 100, manufactured by Rover, kept a promise of a profitable, independent future. In fact Rover failed to post any significant returns during its relationship with Honda (see Table 4), and as Pilkington (1998, p. 7) remarks, when Rover has made little or no cash surplus for the last twenty years, the rate and extent to which new models can be replaced and redesigned is limited.

Apart from that issue, it should be noticed that the influence of Honda-designed models on the Rover's reputation for reliability and quality was radical, notably improving its brand image. As far as productivity levels are concerned, not all Rover's facilities experienced the same changes in their production processes, which help to explain why productivity figures diverge across the plants. After several mistakes and false economies in the early days, mainly due to the difficulties of carrying on a full replication of Honda Japanese facilities in the UK, the Longbridge facility became a champion within Rover of the Honda way. Solihull, the home of Land Rover and Range Rover, has been little influenced by Honda, whereas Cowley only produces Honda-derived products. While Longbridge follows a Toyota approach as regards batch sizes and customers' options, Cowley has followed the approach of a mass producer, more closely associated with the Honda manufacturing approach.

As the venture grew and developed, Rover had come to rely on Honda for the majority of its product development activities (see the production figures in Table 4) as well as the problems and successes of Rover. It has maintained the core skills needed to develop new vehicles, like the Rover 100, but it does not have the financial resources to maintain vehicle development across the full range (see the profit trajectory in Table 4). In fact, the never-ending financial problems led to its sale to British Aerospace (BAe). This sale did not disturb the relationship with Honda Motor, but on the contrary, the relative financial stability strengthened it. 
Table 2. Main features of Rover and Seat before their respective alliances.

\begin{tabular}{|c|c|c|c|c|c|c|c|c|}
\hline & \multicolumn{4}{|l|}{ Rover } & \multicolumn{4}{|l|}{ Seat } \\
\hline & $\begin{array}{l}\text { Before } \\
1973\end{array}$ & $\begin{array}{l}1973 \\
\text { (BMLC) }\end{array}$ & 1977 (BL) & 1979 Alliance & $\begin{array}{l}19501972 \text { 'Quasi } \\
\text { Monopoly' }\end{array}$ & $\begin{array}{l}19741979 \\
\text { 'Competence' }\end{array}$ & 1981 INI & 1982 Alliance \\
\hline $\begin{array}{l}\text { Facilities and } \\
\text { equipment }\end{array}$ & Outdated & Outdated & Downsizing & Re organization & $\begin{array}{l}\text { Progressive } \\
\text { obsolescence }\end{array}$ & $\begin{array}{l}\text { Progressive } \\
\text { obsolescence }\end{array}$ & Outdated & Strong investments \\
\hline Economies of scale & No & No & Re organised & Re organised & $\begin{array}{l}\text { Progressive lost of } \\
\text { focus }\end{array}$ & No & No & $\begin{array}{l}\text { Re organised } \\
\text { (Focused mftg) }\end{array}$ \\
\hline Product portfolio & Outdated & Outdated & Outdated & $\begin{array}{l}\text { Two new models } \\
\text { from Honda }\end{array}$ & $\begin{array}{l}\text { Too wide, } \\
\text { outdated, Fiat } \\
\text { models }\end{array}$ & $\begin{array}{l}\text { Outdated, Fiat } \\
\text { models }\end{array}$ & $\begin{array}{l}\text { Outdated, Fiat } \\
\text { models }\end{array}$ & $\begin{array}{l}\text { Fiat and VW } \\
\text { models }\end{array}$ \\
\hline R\&D capabilities & $\begin{array}{l}\text { Some at } \\
\text { Austin }\end{array}$ & Eroded & Eroded & $\begin{array}{l}\text { Refocused by } \\
\text { Honda }\end{array}$ & None & None at all & None at all & $\begin{array}{l}\text { Refocused by VW, } \\
\text { some section left to } \\
\text { Seat (Ibiza model) }\end{array}$ \\
\hline Supply chain & $\begin{array}{l}\text { Local } \\
\text { suppliers, } \\
\text { No chain }\end{array}$ & $\begin{array}{l}\text { Local } \\
\text { suppliers, } \\
\text { no chain }\end{array}$ & $\begin{array}{l}\text { Local } \\
\text { suppliers, no } \\
\text { chain }\end{array}$ & $\begin{array}{l}\text { Japanese British } \\
\text { Ring }\end{array}$ & $\begin{array}{l}\text { Local suppliers, no } \\
\text { chain }\end{array}$ & $\begin{array}{l}\text { Local suppliers, } \\
\text { no chain }\end{array}$ & $\begin{array}{l}\text { Local suppliers, } \\
\text { no chain }\end{array}$ & $\begin{array}{l}\text { German Spanish } \\
\text { ring }\end{array}$ \\
\hline Quality levels & Very low & Very low & Low & Rising & Very low & Low & Low & Rising \\
\hline Productivity figures & Very low & Very low & Low & Low & Neutral & Low & Low & Rising \\
\hline $\begin{array}{l}\text { Financial strengths/ } \\
\text { weaknesses }\end{array}$ & Very weak & Very weak & Weak & $\begin{array}{l}\text { Injection from } \\
\text { Honda }\end{array}$ & Neutral & Weak & $\begin{array}{l}\text { Relatively } \\
\text { strength } \\
\text { (injection from } \\
\text { INI) }\end{array}$ & $\begin{array}{l}\text { Relatively strength } \\
\text { (injection from } \\
\text { INI) }\end{array}$ \\
\hline Brand reputation & $\begin{array}{l}\text { Poor, but } \\
\text { helped by } \\
\text { domestic } \\
\text { proud }\end{array}$ & Poor & Poor & Rising quickly & $\begin{array}{l}\text { Poor, but helped } \\
\text { by domestic proud }\end{array}$ & Poor & Poor & Rising \\
\hline $\begin{array}{l}\text { Marketing strengths/ } \\
\text { weaknesses }\end{array}$ & Neutral & Neutral & Neutral & $\begin{array}{l}\text { Reinforced by } \\
\text { Honda }\end{array}$ & $\begin{array}{l}\text { Good knowledge } \\
\text { of market }\end{array}$ & $\begin{array}{l}\text { Good knowledge } \\
\text { of both Spanish } \\
\text { and South } \\
\text { American } \\
\text { markets }\end{array}$ & $\begin{array}{l}\text { Good } \\
\text { knowledge of } \\
\text { both Spanish } \\
\text { and South } \\
\text { American } \\
\text { markets }\end{array}$ & $\begin{array}{l}\text { Good knowledge } \\
\text { of German, } \\
\text { Spanish and South } \\
\text { American markets }\end{array}$ \\
\hline Leitmotiv & $\begin{array}{l}\text { Outdated, } \\
\text { fragmented } \\
\text { market }\end{array}$ & $\begin{array}{l}\text { To cut } \\
\text { costs and } \\
\text { retain } \\
\text { market } \\
\text { share }\end{array}$ & $\begin{array}{l}\text { To rationalise } \\
\text { models and } \\
\text { markets }\end{array}$ & $\begin{array}{l}\text { To learn from } \\
\text { Honda how to } \\
\text { organise the } \\
\text { production, the } \\
\text { supply chain and } \\
\text { to faster the NPD } \\
\text { process }\end{array}$ & $\begin{array}{l}\text { Every Spanish } \\
\text { family may have a } \\
\text { Seat car. }\end{array}$ & $\begin{array}{l}\text { To increase } \\
\text { exports to } \\
\text { diminish idle } \\
\text { capacity }\end{array}$ & $\begin{array}{l}\text { To become a } \\
\text { profitable } \\
\text { company with } \\
\text { international } \\
\text { links }\end{array}$ & $\begin{array}{l}\text { To acquire NPD } \\
\text { and R\&D } \\
\text { capabilities, to } \\
\text { develop good } \\
\text { relationships with } \\
\text { its partner }\end{array}$ \\
\hline
\end{tabular}


Table 3. New product development at Rover Honda.

\begin{tabular}{|c|c|c|c|c|c|c|c|}
\hline & \multirow[b]{2}{*}{ Triump Acclaim } & \multicolumn{3}{|l|}{ Rover 200} & \multicolumn{2}{|l|}{ Rover 800} & \multirow{2}{*}{$\begin{array}{l}\text { Rover } 600 \\
\text { (Honda Accord) }\end{array}$} \\
\hline & & Rover 200 (1984) & $\begin{array}{l}\text { Rover 200/400 } \\
(1990)\end{array}$ & $\begin{array}{l}\text { Rover } 400 \text { (Honda } \\
\text { Civic) 1995* }\end{array}$ & Rover 800 & Sterling & \\
\hline New components? & Yes & Yes & $\begin{array}{l}\text { Some engines } \\
\text { from the Rover } \\
800 \text {, some diesel } \\
\text { engines. }\end{array}$ & $\begin{array}{l}\text { New body styling } \\
\text { with mechanical } \\
\text { alterations }\end{array}$ & $\begin{array}{l}\text { Large number of } \\
\text { parts were bought } \\
\text { to Honda, mainly } \\
\text { gearboxes and } \\
\text { engines }\end{array}$ & $\begin{array}{l}\text { Large number of } \\
\text { parts were bought } \\
\text { to Honda, mainly } \\
\text { gearboxes and } \\
\text { engines }\end{array}$ & $\begin{array}{l}\text { Huge investments } \\
\text { and serious } \\
\text { overcapacity } \\
\text { problems }\end{array}$ \\
\hline Equipment and facilities & $\begin{array}{l}\text { New, bought to } \\
\text { Honda }\end{array}$ & $\begin{array}{l}\text { Duplication of } \\
\text { Japanese facilities }\end{array}$ & $\begin{array}{l}\text { Re organised by } \\
\text { Honda }\end{array}$ & Neutral & $\begin{array}{l}\text { Unfitted for the } \\
\text { high number of } \\
\text { versions }\end{array}$ & $\begin{array}{l}\text { Unfitted for the } \\
\text { high number of } \\
\text { versions }\end{array}$ & Honda \\
\hline Whose R\&D? & Honda's & $\begin{array}{l}\text { Honda mostly and } \\
\text { Rover: mechanics } \\
\text { and } 1600 \mathrm{cc} \text { engines }\end{array}$ & $\begin{array}{l}\text { Rover } \\
\text { concentrated all } \\
\text { its efforts in re } \\
\text { styling and } \\
\text { luxurious } \\
\text { appearance }\end{array}$ & $\begin{array}{l}\text { Rover designed } \\
\text { new versions of the } \\
\text { K series engines }\end{array}$ & $\begin{array}{l}\text { Honda mostly; } \\
\text { Rover designed the } \\
2 \text { litres engine }\end{array}$ & Honda & \\
\hline Quality levels & Poor & Poor & Rising & Rising & Neutral & Very poor & Neutral \\
\hline Supply chain & Japanese UK ring & Japanese UK ring & Japanese in UK & Japanese in UK & Japanese in UK & Japanese in UK & Japanese in UK \\
\hline Productivity figures & Low & Low & Low & Low & Low & Very low & Low \\
\hline Commercial success & Yes & Neutral/no & Neutral & Neutral & Neutral & Total failure & Neutral \\
\hline Financial figures & Neutral/Poor & Poor & Poor & Poor & Poor & Very poor & Poor \\
\hline Brand reputation & Rising & Rising & Neutral & Neutral & Neutral & Decreasing & Poor \\
\hline $\begin{array}{l}\text { International distribution } \\
\text { network }\end{array}$ & Neutral & Neutral & Neutral & Neutral & Neutral & Poor & Poor \\
\hline
\end{tabular}

${ }^{*}$ After the take over by BMW 
Table 4. The effects of the alliance on Rover's fortunes.

\begin{tabular}{lllll}
\hline Year & $\begin{array}{l}\text { Turnover } \\
(£ M)\end{array}$ & $\begin{array}{l}\text { Profit (loss) } \\
(£ M)\end{array}$ & Rover units* & Honda units \\
\hline 1981 & 2,869 & $(503)$ & 367,875 & 20,447 \\
1982 & 3,072 & $(300)$ & 311,814 & 58,025 \\
1983 & 3,421 & $(142)$ & 383,141 & 50,042 \\
1984 & 3,402 & 80 & 339,784 & 31,643 \\
1985 & 3,415 & $(138)$ & 385,048 & 65,844 \\
1986 & 3,412 & $(892)$ & 311,231 & 78,737 \\
1987 & 3,096 & $(26)$ & 313,436 & 137,290 \\
1988 & $1,179 \#$ & 35 & 304,605 & 145,970 \\
1989 & 3,430 & 64 & 294,831 & 139,985 \\
1990 & 3,785 & 55 & 229,775 & 187,576 \\
1991 & 3,744 & $(52)$ & 154,046 & 205,905 \\
1992 & 3,684 & $(49)$ & 122,400 & 216,654 \\
\hline
\end{tabular}

Notes: *excluding Land Rover; " part year figure from BAe Report. Source: Adapted from Pilkington (1998, p. 8)

3.2.2. Seat and Volkswagen. The Spanish economic, social, and political conditions of the early 1980s discouraged any privatisation of Seat, but INI was willing to get rid of it. Thus, Seat managers were looking for alternatives to modernise the technological base without altering the workforce scenery. It was not an easy task and several potential allies were contacted, such as the Japanese firms Nissan and Toyota. Finally, Seat was able to reach an agreement with Volkswagen.

In 1982 Seat and Volkswagen signed their strategic alliance, labelled as the 'Acuerdo de Cooperación Industrial, Licencia y Asistencia Técnica', ${ }^{2}$ which was estimated to last seven years. Seat was not allowed to manufacture Volkswagen vehicles until 1984, except for some lot orders of the Passat and Variants models, which would be manufactured at Zona Franca. From 1984 to 1988, Seat would manufacture the VW's models Passat, Santana and Variant. Table 5 shows the continuous increasing pace of VW's badge models manufactured and imported by Seat. This strategy allowed the company to amortise those fixed costs related to the renewal of product and process technologies, and reduced the manufacturing costs of VW badge models. In addition it allowed the increasing of exports from Germany to Spain and its influence area. The size of the exportation network increased from the 599 sale points of 1983 to the 2517 of 1987 . Seat improved its brand image almost immediately, benefiting from the reputation of high quality and reliability that the German vehicles have achieved. Even the Seat logo (badge) was redesigned, as well as the brand image transmitted and publicised to the customers.

As a consequence of the strategic alliance, Seat facilities underwent a profound transformation, that included the upgrading of the workforce at the Landaben and Zona Franca facilities, the modernisation of equipment and plants, and the re-organisation of the supply chain. These changes were aimed at enabling these facilities to manufacture the VW Polo Classic and Coupé at Landaben, Pamplona. The Zona Franca facility was dedicated in 1982 to the manufacturing of the Passat and Variant models. At the same time, old Seat models, such as the Seat 131, 127 Fura, Panda, and Ronda, remained in the portfolio of Seat until 1986, this meant that different process technologies were being used simultaneously at Zona Franca, leading to unbalanced productivity figures. Table 6A summarises these facts.

Seat was able to launch two new models: the Ibiza model in 1984, and the Málaga model in 1985. Only the Ibiza model was a Seat car, because the Málaga model was an adaptation of the VW Jetta. Álvarez and González (1997) affirmed that Seat had a very large portfolio along the period 1983-86, showing a strategy that clearly diverged from the one followed by its competitors at the time. Instead of focusing on the development of new cars, Seat R\&D people started to learn how to incorporate advances from VW models into its newest models, searching for ways to improve

Table 5. The integration of Seat and VW production and marketing plans.

\begin{tabular}{|c|c|c|c|c|c|c|c|c|c|}
\hline \multirow[b]{2}{*}{ Year } & \multicolumn{5}{|c|}{$\begin{array}{l}\text { Car units manufactured and exported by Seat } \\
(1984 \text { 1992) }\end{array}$} & \multicolumn{4}{|c|}{$\begin{array}{l}\text { Car models sold and imported by Seat for its domestic } \\
\text { market }(1984 \text { 1992) }\end{array}$} \\
\hline & Seat & VW & $\begin{array}{l}\text { Exported } \\
\text { (Seat } \\
\text { badge) }\end{array}$ & $\begin{array}{l}\text { Exported } \\
\text { (VW badge) }\end{array}$ & $\begin{array}{l}\text { VW's \% of } \\
\text { total exports }\end{array}$ & SEAT (1) & VW Audi (2) & TOTAL $(1)+(2)$ & $\begin{array}{l}\text { Imported } \\
\text { VW Audi } \\
\text { units }\end{array}$ \\
\hline 1984 & 225.548 & 53.438 & 131.895 & 17.038 & $11.44 \%$ & 128.334 & 22.360 & 150.694 & 1.730 \\
\hline 1985 & 224.892 & 95.319 & 153.562 & 53.852 & $25.96 \%$ & 85.923 & 42.968 & 128.891 & 5.759 \\
\hline 1986 & 231.885 & 106.663 & 120.254 & 69.197 & $36.53 \%$ & 99.866 & 39.383 & 148.434 & 9.185 \\
\hline 1987 & 275.151 & 131.240 & 158.118 & 87.863 & $35.72 \%$ & 123.867 & 39.894 & 187.529 & 23.768 \\
\hline 1988 & 327.737 & 105.745 & 193.499 & 75.941 & $28.18 \%$ & 131.238 & 87.947 & 219.185 & 55.028 \\
\hline 1989 & 350.034 & 124.115 & 223.165 & 98.699 & $30.66 \%$ & 125.419 & 113.839 & 239.258 & 65.035 \\
\hline 1990 & 361.629 & 143.750 & 243.165 & 125.406 & $33.99 \%$ & 118.778 & 96.901 & 215.679 & 71.308 \\
\hline 1991 & 360.510 & 191.700 & 260.623 & 177.595 & $40.53 \%$ & 97.198 & 81.757 & 178.955 & 56.233 \\
\hline 1992 & 356.210 & 222.222 & 253.313 & 212.092 & $45.67 \%$ & 102.208 & 80.546 & 182.754 & 65.430 \\
\hline
\end{tabular}

Source: González (1998), compiled from Company Reports and Accounts 
Table 6A. New product development at Seat VW.

\begin{tabular}{|c|c|c|c|c|c|c|c|}
\hline & \multicolumn{2}{|l|}{ Fiat models } & \multicolumn{3}{|l|}{ Polo (WV) } & \multirow{2}{*}{$\frac{\text { Ibiza (Seat) }}{(1984)}$} & \multirow{2}{*}{$\frac{\text { Málga (Seat) }}{(1985)}$} \\
\hline & Panda & Ritmo & Polo & Classic & Coupé & & \\
\hline New Model? & No & No & No & Yes & Yes & Yes & $\begin{array}{l}\text { Re styling of Jetta } \\
\text { VW }\end{array}$ \\
\hline New components? & No & No & No & Yes & Yes & Yes & No \\
\hline Equipment and Facilities & Outdated & $\begin{array}{l}\text { Outdated } \\
\text { overcapacity }\end{array}$ & $\begin{array}{l}\text { Re organised by } \\
\text { VW }\end{array}$ & $\begin{array}{l}\text { Re organised by } \\
\text { VW }\end{array}$ & $\begin{array}{l}\text { Re organised by } \\
\text { VW }\end{array}$ & $\begin{array}{l}\text { Re organised by } \\
\text { Seat and VW }\end{array}$ & $\begin{array}{l}\text { Re organised by } \\
\text { VW }\end{array}$ \\
\hline Whose R\&D? & $\begin{array}{l}\text { FIAT engines } \\
\text { and Seat styling }\end{array}$ & $\begin{array}{l}\text { FIAT engines } \\
\text { and Seat } \\
\text { styling }\end{array}$ & VW & VW & VW & Seat & VW \\
\hline Economies of scale & No & No & Yes (for VW) & Yes (for VW) & Yes (for VW) & $\begin{array}{l}\text { Yes for VW, rising } \\
\text { for Seat }\end{array}$ & $\begin{array}{l}\text { Yes for VW and } \\
\text { Seat }\end{array}$ \\
\hline Quality levels & Poor & Poor & Rising & Rising & Rising & Rising & Rising \\
\hline Supply chain & Local, no chain & Local, no chain & $\begin{array}{l}\text { German Spanish } \\
\text { ring }\end{array}$ & VW system & VW system & Seat VW systems & VW supply system \\
\hline Productivity figures & Low & Low & Neutral & Neutral & Neutral & Neutral & Neutral \\
\hline Commercial success & Yes & Neutral & Yes & Yes & Yes & Yes & Yes \\
\hline Financial Figures & Poor & Poor & Neutral & Neutral & Neutral & Good & Good \\
\hline Brand reputation & Neutral & Neutral & Rising & Rising & Rising & Good & Good \\
\hline $\begin{array}{l}\text { International distribution } \\
\text { network }\end{array}$ & Good & Good & Good & Good & Good & Good & Good \\
\hline
\end{tabular}


Table 6B. New product development at Seat, after its take over by WV

\begin{tabular}{lll}
\hline Year & Launching of new models & Designed and engineered by: \\
\hline 1987 & $\begin{array}{l}\text { 3 new versions of Málaga } \\
\text { First re styling of Ibiza }\end{array}$ & mainly VW, with some Mediterranean touch \\
& Seat, with the VW's platform \\
1989 & Ibiza II & VW: platform and core, high added value components/Seat: Chassis and \\
1990 & Toledo & Mediterranean touch \\
& VW & Veat, with the VW's platform \\
1991 & Ird re styling of Polo & VW: platform and core, high added value components/Seat: Chassis and \\
1992 & Córdoba Style & 'Mediterranean touch' \\
& VW: platform and core, high added value components/Seat: Chassis and \\
1995 & Inca & Mediterranean touch \\
& Auto Europa, with high levels of involvement for Seat \\
1996 & Alhambra & Mainly Seat, with a VW's platform. \\
1997 & Arosa & Mainly Seat, with a VW's platform \\
1998 & New Toledo &
\end{tabular}

the manufacturing process and even the design of the VW badge models manufactured in Spain.

\subsection{The end of the alliances}

In early 1994, BMW took over the majority of Rover. According to Hudson and Schamp (1995, p. 236), the merger opened new market segments to BMW, broadening their product portfolio, mainly the small sized cars (Mini, Rover 100) and the off-road vehicles (Land Rover and Range Rover). From the production and operations management point of view, it allowed BMW to use its diesel motor in the Rover models, as well as to achieve increasing economies of scale through the shared use of body platforms, as in the case of the BMW 5 and Rover 800. As a result of the take-over Honda almost immediately decided to pull out of its fifteen years partnership with Rover.

Two years into the agreement, in 1986, Volkswagen decided to end its alliance with Seat and to acquire the Spanish firm. Seat became the third member of the VW Consortium, together with VW and Audi, enjoying some autonomy to manage the distribution channels of its own vehicles. From 1987 till 1990 Seat concentrated all its R\&D efforts in the re-styling of its Ibiza and Málaga models (see Table 6B). The Landaben plant was renewed in 1987 to manufacture the third face-lifts of the VW Polo Coupé, and new investments took place in 1990 and 1991, to increase the manufacturing capacity for Polo engines up to 1200 per day, and vehicles, up to 1000 per day, respectively. In 1988 relevant investments were made in Zona Franca, aimed at reducing the most relevant bottlenecks, and preparing the plant for the launch of the new model Toledo. This new model combines the VW platform with a 'Mediterranean' design of its 'hüt'. Something similar took place in 1991 and 1992 with the Ibiza New Style, and the Córdoba, respectively. A new state of the art facility was built in 1993, known as the Martorell plant, and the Zona Franca facility was closed down very soon afterwards, moving the manufacturing of both Seat cars and several badge models to Martorell.

During the eleven-year period after the end of the alliance with VW Seat designers and engineers have been able to design two new cars, developed from the platform imposed by VW to all its Consortium members. These cars are the Arosa model, launched in 1997, and the 'New Toledo' model, launched in 1998. Seat has also participated in the design of the Inca (1995) and Alhambra models (1996). We consider these success as very relevant to our study, since they show that Seat's interest in developing new models, as expressed by its 1983 Corporate Strategic Plan, is finally coming to a happy end.

\section{Analysis of the effects of the strategic alliances}

The two alliances that we analyse here are very similar from the point of view that each of the 'teacher' partners had the same reasons to agree to having the weaker firms as 'student' partners. Both Honda and Volkswagen were seeking to expand its geographic scope of operations, to achieve economies of scale and to reinforce their links with their suppliers. This is why Rover and Seat's knowledge of local economic, political, and cultural environments, as well as their contact with the rings of domestic suppliers, were considered an essential contribution to the success of the joint venture.

They also coincide in that they were two nationalised firms, technologically weak, which were looking for alternatives to reinforce their R\&D capabilities, and to incorporate new models in their product portfolios, as their last opportunity to survive in a hostile environment. Neither Rover, nor Seat, had access to a continuous fund raising system that provided them with the financial resources required to compete successfully in the European car market of the eighties. 
However, they differ not only in the form in which their strategic alliances were initiated and how they ended, but in the trajectory of their learning processes as well.

In the Rover case, the official explanation for signing the agreement with Honda was that it could be a route for Rover to learning from Honda's manufacturing approaches. Nothing was said about learning how to develop new products as the leading issue in forming the alliance, but about the assembly of a Japanese model while the Rover people, instead, get ready to launch the Montego/Maestro model. In the Seat case Volkswagen was chosen as a teacher partner with the main intention of enlarging Seat's product range by incorporating new specialised vehicles as well as new key components, installed in the new models or in updated versions of old models, such as engines or transmissions.

Very soon after the start-up of the alliance with Honda, Rover managers '... realised that the company was to be in a situation where $70 \%$ of the car would be bought-in' (Schill et al., 1994, p. 262). They started then to work hard in order to built vertical alliances in those parts of the value-added chain that would link and support the internal centres of excellence. Besides, they tried to carefully select those components and systems that customers perceive as important technological signals. As it is shown in Table 4, most of these efforts ended up as body-styling and face-lifting of Honda previous models, some minimal mechanical alterations, and a very limited capability to design one key component: the engine. Effectively, during the time that the alliance was alive, Rover R\&D departments were able to design and manufacture six different engines for the different versions of the Rover 200, 400, and 800. Apart from that, Rover became more and more involved in manufacturing badge products and in 'roverising' the Honda models. It forgot its initial objective of achieving a 'convergent development' (Nakamura et al., 1996), which would allow the firm to learn from Honda, while keeping its distinctive competencies in engines and key components design related activities. Consequently, when we analyse whether or not Rover developed those core capabilities linked to the new product design and development processes, the available information is contradictory. On the one hand, by the time the alliance ceased, Rover was able to design a new car, the Rover 100, but this model alone was not sufficiently profitable to save the firm from red figures; it was capable of designing some new engines as well. On the other hand, one valuable capability that Rover has learnt from its teacher partner is to tailor existing designs from other manufacturers to produce 'Roverised' products.

These supposed learning achievements have not being accompanied by financial success. As Pilkington has already described (Pilkington, 1998), Rover was completely unable to post any significant return during its relationship with Honda.
Thus, we are facing a case where the financial constraints were preventing a firm from emphasising its R\&D capabilities; the firm, lacking this financial support looked for an alternative way to access the required knowledge instead of its acquisition, and signed an strategic alliance with a stronger partner. The stronger partner never lost money with the alliance, but the weaker was not able to say good-bye to the red figures: from 1981 till 1993, Rover only got profit figures, rather low figures, on five occasions. Thus, a strange 'divergent development' effect took place, wherein Rover forgot, or was forced to forget, about the intention to learn Honda's manufacturing techniques and supplier relationships; it devoted most of its capabilities to 'roverise' Honda models. As Pilkington (1998, p. 7) points out: '...Whatever strength of resolution Rover may have felt at the start of its relationship with Honda, (it) was quickly lost as the venture grew and developed, sapped by an ambitious desire for more Honda models'.

As it concerns the Seat case, it is important to take into account that VW's strategy along the last two decades has been an upgrading of the functions of its core. This means the allocation of the manufacturing of the core components, power train, suspension, cockpits, engines, and platforms, in Wolfsburg. This strategy explains why VW never helped Seat to increase those of its core capabilities associated with the design and development of the key components of its vehicles. Thus, it is very likely that VW did not even allow the Spanish firm to manufacture high valueadded elements, as a means of constraining the potential development of some 'learning by doing' effect. So, we can consider the Seat and VW strategic alliance as one of the type of 'divergent development' (Nakamura et al., 1996), since there was no technological overlap between Seat and Volkswagen during its relationship. At that time, any kind of knowledge and capabilities that Seat might have required for the assembly of the badge models was accessed from VW.

Nevertheless, it is very important to remark that the Spanish firm had a clearly defined strategy at the moment of signing its agreement with VW. According to such strategy, Seat was intended to design and manufacture a model of its own. Seat acknowledged that, in spite of the fact that it could afford such a goal alone, the firm was aware of the fact that it will not survive in the medium and long term with just one model. Thereby, Seat recognised its strong need to collaborate and to learn from a partner on the basis of a long-term commitment.

According to the goals of its strategic corporate plan, Seat launched the Ibiza model in 1984. For that purpose, huge investments took place, which were financed by the Spanish firm. It also participated very actively in the upgrading of its facilities in order to assembly the VW's models included in the strategic agreement. Six years later, the Toledo model was 
launched, and it combines the VW platform with a 'Mediterranean' design of its 'hüt'. This is the first example of how Seat increased its absorptive capacity, i.e. its ability to value, assimilate, and apply knowledge from a former learning alliance partner (Lane and Lubatkin, 1998, p. 462); at the same time it grew familiar with the set of organisational problems of VW. This situation has been experienced again with the launching of the Ibiza New Style (1991), and the new model Córdoba (1992). Seat has also participated in the design of the Inca (1995) and Alhambra models (1996). Very recently, Seat has played a really significant role in the design and manufacture of the Arosa (1997) and New Toledo (1998) models. From those achievements and developments we can infer that a kind of 'convergent development' (Nakamura et al., 1996) has happened to emerge. An interesting organisational learning effect has taken place in Seat, which may have been motivated by its strategic alliance with VW as well as by the way Seat managed that alliance.

We can summarise from these cases that weaker, student partners, can experience some organisational learning linked to new product development processes when some conditions take place. First, the weaker firm has to have a clear strategy and not deviate from it, as Seat did when it launched the Ibiza and kept it in its production plans and products portfolio. Second, the weaker firm should not concentrate on R\&D efforts devoted to key components of its products unless these products already exist. Rover seems to have put to much effort in designing engines, in spite of the fact that Honda designs better engines that Rover does, and that Rover did not have new models wherein to place the new engines. In contrast, Seat concentrated its efforts in developing non-key components for its VW's badge models, a decision that proved to be much more profitable in the long term. Thirdly, the weaker partner should try to adapt itself to assemble the models of the stronger partner just as the stronger partner assembles them, instead of modifying the models to adapt them to its own conditions. By acting this way, not only is the weaker partner self-limiting its learning possibilities, but it is also constraining the success of its partner's products. When this happens, financial success is prevented, and the stronger partner loses interest on the alliance. Seat tried very hard to manufacture the VW's models more cheaply and better than those manufactured by VW itself. It succeeded in this initiative, and VW's interest in Seat did not decrease. Unfortunately Rover faced some problems when assembling the Japanese models, which helped to diminish its probabilities to be acquired by Honda. These facts are consistent with previous studies, which suggest that learning improves the performance of the students and makes the performance of both students and teachers more reliable (March, 1991).

\section{Managerial implications and suggestions for further research}

This study provides some guidelines for managers when it comes to forming successful strategic alliances with a view to developing the unique assets of the companies involved. Forming the alliances needs to be considered very carefully by the participating companies.

The cases analysed here fulfil the prerequisites suggested by Beamish and Inkpen (1995, p. 34) for an alliance to become operational. Both Rover and Seat enjoyed, prior to the venture, three broad areas of knowledge: customer knowledge, manufacturing product and process knowledge, and local operational knowledge. From their analysis we can conclude that the learning that takes place within alliances is more complex than most literature on this topic suggests. In particular, the outstanding problem we have analysed in this article is that one where firms with weak technological basis, lacking the financial resources required to adequately invest in R\&D processes, NPD activities, etc., consider to substitute those investments by the signing of a strategic technology alliance with a teacher partner.

The existing literature does not help managers too much in this decision making process. Firstly, most studies consider that both partners enjoy the same position along the alliance, thus leading to situations where there are learning opportunities for the two partners. Secondly, there is a scarcity of literature considering the financial side of learning alliances, which is like implicitly admitting that there are no financial issues linked to this process. Thirdly, there are

Table 7. Competitive capabilities developed by Rover and Seat as results of their respective strategic alliances.

- Lower costs: due to the out sourcing practices and the collaborative manufacturing

- Technology transfer: new production methods were implemented, and new equipment was installed to manufacture both the badge and own vehicles

- Quality improvement

- Cycle reduction: up to one third below the cycle time before the alliance

- Europeanisation: the distribution networks expanded notoriously in both cases

- Flexibility: both companies were able to fill very quickly their customers orders as a consequence of the high commonality between the car components

- JIT procurement 
not many articles devoted to the analysis of failed learning alliances, which may be taken as an indicator of the good health of such kind of alliances. This article's position clearly differs from the existing literature, and it is expected to help forge a better alignment between academic descriptions and prescriptions and the reality faced by managers.

First at all, it is worthwhile to remark that both Rover and Seat developed some common competitive capabilities as a consequence of their strategic alliances with Rover and Honda. They are summarised in Table 7.

The Rover and Seat cases also show that 'teacher' partners do limit the transfer of knowledge to their 'student' allies; this is to prevent 'students' 'overtaking' their 'teachers'. Thus, the scope and length of the learning process will be constrained by this. Whenever the teacher partner is heavily focused on financial performance issues, it will be less concerned with reinforcing the learning processes of its students; the students under such circumstances might by themselves need to generate resources to compensate for that effort. At such times the competitiveness of the teacher cannot be eroded. The Rover case provides empirical evidence for the Inkpen (1998, p. 227) suggestion that in the face of poor alliance performance, the teacher firm will become reluctant to commit to or even try out proposals generated at the alliance level. Thus, while poor performance can lead to myopia that acts as a barrier to knowledge creation, the student partner may feel that the alliance does not yield satisfactory organisational performance because learning opportunities have been unexploited. This was the feeling of Rover managers when they sold the company to BMW.

So, a student firm with financial problems that is willing to learn from a teacher partner by means of a strategic alliance should take into account that it will only be allowed a limited learning opportunity. Some of its assets may be taken as hostage by the teacher partner. When trying to protect its assets, the student is caught in a dilemma, whereby, as stated by Søfrensen and Reve (1998, p. 151) 'on the one hand it needs to protect its own specific assets, and on the other it wishes to share its assets in the strategic alliance'.

As the Seat case illustrates, the Spanish firm went on with its goal of developing its own model, in spite of its many difficulties, and even after signing the agreement with VW. Its commitment allowed the firm to keep one specific asset without compromising its relationships with VW. Our results suggest the need for a richer conceptual framework in considering the effects of alliance activity on firm-specific knowledge and capabilities. The article suggests a starting point for further specialised research. For instance, our study can be extended to the learning process of the British and Spanish OEMs industries, to identify how their new products and process development activities have been affected by the technological dependence of some of its main customers.

\section{Acknowledgements}

This research is partially funded by the Spanish Ministry of Educación y Cultura, Dirección General de Enseñanza Superior (DGES) projects PB94-0372, PB97-0089, and PR95-583. The authors wish to thank two anonymous reviewers and the editors for their helpful comments and suggestions. The authors also thank J. Bilbao, C. Carr, S. Carmona, E. Huertas, and V. Ripoll for their comments on an earlier draft of the manuscript.

\section{References}

Álvarez, M.J. and González, P. (1997) La internacionaliza ción de Seat: de Zona Franca a Martorell, pasando por Wolfsburg. Economia Industrial, 314, 151170.

Anderson, E. (1990) Two firms, one frontier: on assessing joint venture performance. Sloan Management Review, 31, 2, 1931 .

Barrie, C. (1995) Rover 'marriage' with Honda to end. The Guardian, 29 August, 11.

Beamish, P.W. and Inkpen, A. (1995) Keeping international joint ventures stable and profitable. Long Range Planning, 28, 3, 2636.

Bertodo, R. (1990) The collaboration vortex: anatomy of a European Japanese alliance. Japanese Motor Business, June, 2943.

Burgner, E. (1986) Global Strategy: a Systematic Approach. Un published Ph.D. Thesis, MIT.

Conti, S. and Enrietti, A. (1995) The Italian automobile industry and the case of Fiat: one country, one company, one market? In Hudson, R. and Schamp, E.W. (eds) Towards a New Map of Automobile Manufacturing in Europe? New Production Concepts and Spatial Restructur ing. European Science Foundation, pp. 117146.

Contractor, F.J. and Lorange, P. (1988) Why should firms co operate? The strategic and economics basis for co operative ventures. In Contractor, F.J. and Lorange, P. (eds) Co operative Strategies in International Business. Lexington MA: Lexington Books.

Dogson, M. (1993) Learning, trust, and technological collaboration. Human Relations, 46, 7795.

Doz, Y.L. (1996) The evolution of co operation in strategic alliances: initial conditions or learning processes. Strategic Management Journal, 17, 5583.

Edwardes, M. (1983) Back from the Brink. London.

Gannon, M. (1993) Towards a composite theory of foreign market entry mode choice: the role of marketing strategy variables. Journal of Strategic Marketing, 1, 1, 4154.

Geringer, J.M. and Hebert, L. (1991) Measuring perfor mance of international joint ventures. Journal of Interna tional Business Studies, 22, 2, 49263.

Glaister, K.W. and Buckley, P.J. (1996) Strategic motives for international alliance formation. Journal of Management Studies, 33 3, 301332. 
Grant, R.M. and Baden Fuller, C. (1995) A knowledge based theory of inter firm collaboration. Academy of Management Best Paper Proceedings, 1721.

González, P. (1998) La Influencia de la Privatización sobre la gestión de las empresas: estudio del caso de Seat, S.A. Un published Ph.D. Thesis. Universidad de Las Palmas de Gran Canaria, Spain.

Hagedoorn, J. and Narula, R. (1996) Choosing organisa tional modes of strategy technology partnering: interna tional and sectorial differences. Journal of International Business Studies, $2^{\text {nd }}$ Quarter, 265284.

Hamel, G. (1991) Competition for competence and inter partner learning within international strategic alliances. Strategic Management Journal, 12, 83103.

Harrigan, K.R. (1985) Strategies for Joint Ventures. Lex ington MA: Lexington Books.

Hayes, R., Pisano, G. and Upton, D. (1996) Strategic Operations Competing through Capabilities. New York: Free, p. 420.

Huber, G.P. (1991) Organisational learning: the contributing processes and a review of the literatures. Organization Science, 2, 88117.

Hudson, R. and Schamp, E. (1995) Interdependent and uneven development in the spatial reorganisation of the automobile production systems in Europe. In Hudson, R. and Schamp, E.E. (eds) Towards a new map of Automobile Manufacturing in Europe? New Production Concepts and Spatial Restructuring. European Science Foundation.

Inkpen, A.C. (1995) The Management of International Joint Ventures: An Organisational Learning Perspective. Lon don: Routledge.

Inkpen, A.C. (1998) Learning, knowledge acquisition, and strategic alliances. European Management Journal, 16, 2 , 223229

Inkpen, A.C. and Beamish, P.W. (1997) Knowledge, bargaining power and international joint venture stability. Academy of Management Review, 22, 177202.

Inkpen, A.C. and Crossan, M.M. (1995) Believing is seeing: joint ventures and organisation learning. Journal of Management Studies, 32, 595618.

Jarillo, J.C. (1988) On strategic networks. Strategic Manage ment Journal, 9, 3141.

Kobayashi, N. (1988) Strategic alliances with Japanese firms. Long Range Planning, 21, 2, 2934.

Kogut, B. (1988) Joint ventures: theoretical and empirical perspectives. Strategic Management Journal, 9, 319332.

Lane, P.J. and Lubatkin, M. (1998) Relative absorptive capacity and interorganizational learning. Strategic Man agement Journal, 19, 461477.

March, J.G. (1991) Exploration and exploitation in organi sational learning. Organization Science, 2, 7187.

Mariti, P. and Smiley, R.H. (1983) Co operative agreements and the organisation of industry. The Journal of Industrial Economics, XXXI, 4, 43751.
Mowery, D.C., Oxley, J.E. and Silverman, B.S. (1996) Strategic alliances and interfirm knowledge transfer. Strategic Management Journal, 17, 7791.

Nakamura, M., Shaver, J.M. and Yeung, B. (1996) An empirical investigation of joint venture dynamics: evidence from US Japan joint ventures. International Journal of Industrial Organization, 14, 521541.

Pilkington, A. (1996a) Learning from joint venture: the Rover Honda relationship. Business History, 38, 1, 90114.

Pilkington, A. (1996b) Transforming Rover, Renewal against the Odds, 1981 1994. Bristol Academic Press.

Pilkington, A. (1998) Strategic Alliance and Dependency in Design and manufacture: The Rover Honda Case. Paper presented at the 1998 Aston (UK) Conference.

Pucik, V. (1988) Strategic alliances, organisational learning and competitive advantage: the HRM agenda. Human Resource Management, 27, 1, 7793.

Ritcher, F J. and Vettel, K. (1995) Successful joint ventures in Japan: transferring knowledge through organisational learning. Long Range Planning, 28, 3, 3745.

Savary, J. (1995) Competitive strategies in the world market: the case of Renault and the emergence of a European group? In Hudson, R. and Schamp, E.E. (eds) Towards a New Map of Automobile Manufacturing in Europe? New Production Concepts and Spatial Restructuring. European Science Foundation, pp. 147172.

Schill, R., Bertodo, R.G. and McArthur, D.N. (1994) Achieving success in technology alliances: the Rover Honda strategic collaboration. R\&D Management, 24, 3, 261277.

Simonin, B.L. and Helleloid, D. (1993) Do organisations learn? An empirical test of organisational learning in international strategic alliances. In Moore, D. (ed.) Academy of Management Best Paper Proceedings 1993.

Sørensen, H.B. and Reve, T. (1998) Forming strategic alliances for asset development. Scandinavian Journal of Management, 14, 3, 151165.

Teece, D. and Pisano, G. (1994) The dynamic capabilities of firms: an introduction. Industrial and Corporate Change, 3, 3, 537556 .

Tsang, E.W. (1998) Motives for strategic alliance: a resource based perspective. Scandinavian Journal of Management, 14, 3, 207221.

Westney, D.E. (1988) Domestic and foreign learning curves in managing international co operative strategies. In Contractor, F.J. and Lorange, P. (eds) Cooperative Strategies in International Business. Toronto: Lexington Books, 33946

\section{Notes}

1. Instituto Nacional de Industria ('National Institute for the Industry').

2. Agreement for Industrial Cooperation, Licensing and Technical Support. 